Oleksandr KASHCHUK

(Lwów, Uniw. Iwana Franki)

\title{
POSIADANIE CNÓT JAKO PRZEDSMAK NIEBIAŃSKIEGO ŻYCIA W NAUCZANIU GRZEGORZA WIELKIEGO
}

Już W starożytności przedchrześcijańskiej cnota stanowiła przedmiot zainteresowania wielu wybitnych autorów, jak Sokrates ${ }^{1}$, Platon ${ }^{2}$, Arystoteles ${ }^{3}$, stoicy $^{4}$, czy Plotyn ${ }^{5}$. Większość z nich traktowało cnotę jako środek, który umożliwia człowiekowi wkroczenie do świata boskiego. Takie przekonanie rozwijali autorzy chrześcijańscy czasów późnego antyku, którzy wykorzystując osiagnięcia filozofów przedchrześcijańskich, akomodowali je do ideałów zaczerpniętych z Pisma Świętego. Do tych autorów należy m.in. Grzegorz Wielki († 604). Zgodnie z jego nauczaniem człowiek z natury pragnie łączności

\footnotetext{
${ }^{1}$ Por. Plato, Gorgias 470e; Apologia 29d-30b, 30d i 41d; Charmides 154d-e; Aristoteles, Ethica Nnicomachea Z 13, 1144b; zob. J. Brun, Sokrates, thum. H. Igalson-Tygielska, Warszawa 1999, 81-84; J. Krońska, Sokrates, Warszawa 2001, 109-130; C. Głombik, Oblicza szczęścia, Warszawa 1982, 16-22; A. Krokiewicz, Sokrates. Etyka Demokryta i hedonizm Arystypa, Warszawa 2000, $74-$ 82 i 221.

${ }^{2}$ Por. Plato, Phaedo 69a-d; Theaetetus 176; Meno 87-89; Gorgias 470; Protagoras 360d-361; Respublica IX 580c; Leges IV 716-717; Symposium 210e-211b; Phaedrus 249d; zob. G. Vlastos, Platonic studies, Princeton 1981, 111-139; J.A. Wojtczak, O filozofii Ksenokratesa z Chalcedonu, Warszawa 1980, 76; K. Leśniak, Platon, Warszawa 1993, 63-64.

${ }^{3}$ Por. Aristoteles, Ethica nicomachea A 1, 1094a; A 2, 1094a; A 4, 1095a; I 4, 1166a; K 7, 1178a; A 7, 1097b-1098a; A 13, 1102b; B 6, 1106a-1107a; E 1, 1129b; Z 7, 1141a; Z 1; Z 5, 1140b; Z 12, 1144a; K8, 1178b; zob. K. Leśniak, Arystoteles, Warszawa 1965, 71-72; Głombik, Oblicza, s. 54-58; A.M. Ioppolo, Virtue and happiness in the first book of the „Nicomachean Ethics”, w: Studi sull'etica di Aristotele, red. A. Alberti, Naples 1990, 119-148; I. Świtała, Filozofowie o szczęściu. Od Platona do Milla, Częstochowa 2003, 16-17.

${ }^{4}$ Por. Stobaeus, Anthologium II 77, 16; II 98, 20; II 100, 15; Diogenes Laertios, Vitae philosophorum VII 89; zob. M. Forschner, Die stoische Ethik, Darmstadt 1995, 212-226.171-182; G. Striker, The role of ,, oikeiosis” in stoic ethics, „Oxford studies in ancient philosophy” 1 (1983) 145-167; Świtała, Filozofowie, s. 26-28; G. Lesses, Virtue and the goods of fortune in stoic moral theory, „Oxford Studies in Ancient Philosophy” 7 (1989) 95-127; Głombik, Oblicza, s. 98-102.

${ }^{5}$ Por. Plotinus, Enneades I 2, 1 i 3; I 4, 13; zob. D. Dembińska-Siury, Plotyn, Warszawa 1995, 69-70; L.P. Gerson, Plotinus, London 1994, 199; G. Reale, Historia filozofii starożytnej, thum. E.I. Zieliński, t. 4, Lublin 1999, 591; J. Bańka, Plotyn i odwieczne pytania metafizyki, t. 2: O rzeczywistości prawdziwej, pozornej i stanach mistycznych, Katowice 1996, 507-510.
} 
z Bogiem ${ }^{6}$, która stanowi zadatek niebiańskiej łączności z Nim7. Celem niniejszego artykułu jest prezentacja poglądów Papieża Grzegorza na temat cnót oraz ich posiadania, rozumianego jako przedsmak niebiańskiego życia. W pierwszym punkcie zostanie zaprezentowana nauka o cnotach u Grzegorza Wielkiego. Punkt drugi zostanie poświęcony przedstawieniu Grzegorzowego przekonania, że posiadanie cnót stanowi podstawę duchowej więzi z Bogiem W życiu ziemskim, a punkt trzeci - rozumieniu duchowej łączności z Bogiem w życiu ziemskim jako przedsmaku niebiańskiego życia.

1. Nauka o cnotach. Grzegorz Wielki naucza, że cnoty są dobrami duchowymi ${ }^{8}$. Siedliskiem duchowych dóbr posiadanych przez człowieka jako bytu cielesno-duchowego jest jego wnętrze, o którym decyduje dusza (virtutes animae) $)^{9}$, a dokładniej rozumna jej część, określana jako: umysł (virtutes mentis $)^{10}$, serce (virtus cordis $)^{11}$ czy duch (animus) ${ }^{12}$. Rozumna część duszy jest zasadą wnętrza człowieka, czyli zasadą jego duchowości ${ }^{13}$. Autor Moraliów

${ }^{6}$ Por. Gregorius Magnus, Moralia XXXII 10, 12, CCL 143B, 1637: „Ex natura quippe bene condita est nobis intentio, quae surgat in Deum; [...]"; zob. S. Rosik, Dażenie do nieba jako nakaz historiozbawczy w doktrynie Grzegorza Wielkiego, RTK 22 (1975) z. 3, 33-43; tenże, Finalizm życia chrześcijańskiego w świetle twórczości papieża Grzegorza Wielkiego, Lublin 1980, 199-205; M. Casey, Spiritual desire in the Gospel Homilies of Saint Gregory the Great, „Cistercian Studies” 16 (1981) 299-300. Chociaż w nauczaniu Grzegorza wszyscy ludzie mają zaszczepione w swojej naturze pragnienie Boga, nie wszyscy jednak dążą do Niego. Ten fakt wyjaśnia Grzegorz Wielki przekonaniem, że przyzwyczajenie człowieka do niegodziwości przywiązuje go do świata i niszczy to, co w człowieku jest naturalne; por. Gregorius Magnus, Moralia XXXII 10, 12, CCL 143B, 1637: „Ex natura quippe bene condita est nobis intentio, quae surgat in Deum; sed ex conversatione nequiter assueta inest voluptas, quae praesens premat in saeculum".

${ }^{7}$ Por. Gregorius Magnus, Moralia XXXV 17, 44; XXXV 8, 17; VII 25, 30; VIII 7, 12; VIII 8, 14; XIX 25, 42.

${ }^{8}$ Por. tamże II 43, 68; XXIII 24, 48; II 61, 66; XXVII 46, 75; XXIV 8, 19; XVI 22, 27.

${ }^{9}$ Por. tamże XXX 18, 59; XXIII 26, 32; zob. P. Gwiazda, Życie kontemplacyjne wedtug św. Grzegorza Wielkiego, Warszawa 2001, 155.

${ }^{10}$ Por. Gregorius Magnus, Moralia XXIII 25, 49; zob. Gwiazda, Życie kontemplacyjene, s. 155. Na temat nabywania cnót w nauczaniu Grzegorza Wielkiego por. O. Kashchuk, Droga doskonalenia chrześcijańskiego w nauczaniu Grzegorza Wielkiego, RBL 61 (2008) 143-153.

${ }^{11}$ Por. Gregorius Magnus, Moralia I 35, 49.

${ }^{12}$ Por. tamże VIII 10, 20; zob. Gwiazda, Życie kontemplacyjne, s. 155.

${ }^{13}$ Por. Gregorius Magnus, Moralia XIV 35, 42; X 15, 27; zob. C. Dagens, Saint Grégoire le Grand. Culture et expérience chrétiennes, Paris 1977, 178-179; J.J. O'Donnell, , The Holiness of Gregory, w: Gregory the Great. A symposium, ed. J.C. Cavadini, London 2001, 72. W tym przekonaniu Grzegorz Wielki nawiązuje do wcześniejszej myśli filozoficzno-patrystycznej. W platonizmie dusza jako element duchowy i ciało jako element przynależący do świata materialnego były uważane za rzeczywistości o nieporównywalnym znaczeniu. Według Platona, dusza ludzka jest trojaka: rozumna, zmysłowo-popędliwa i zmysłowo-pożądliwa (wegetatywna). Duszę zmysłowo-popędliwą posiadają zwierzęta, a duszę wegetatywną także i rośliny, natomiast duszę rozumną posiada tylko człowiek, którego ona wyróżnia spośród żywej przyrody, por. Plato, Timaeus 69a-71a; Respublica IX 580d; zob. G. Dogiel, Antropologia filozoficzna, Kraków 1992, 12-13. Oprócz ożywiania ciała Platon 
często przeciwstawia duchowe wnętrze (intus, intrinsecus, internus, intimus) człowieka temu, co znajduje się na zewnątrz (exterior, exterius, extrinsecus, foris, foras $)^{14}$.

Zgodnie z nauczaniem Grzegorza Wielkiego, fundament dobrego postępowania stanowią cnoty kardynalne: roztropność (prudentia), umiarkowanie (temperantia), męstwo (fortitudo) i sprawiedliwość (iustitia) ${ }^{15}$. Przez nie i przez inne wypływające z nich cnoty dusza podnosi się na wyżyny sprawiedliwego życia ${ }^{16}$. Autor nie wyszczególnia którejś spośród cnót kardynalnych jako najważniejszej i uprzedniej w stosunku do innych, ani nie podaje ich definicji ${ }^{17}$.

przypisał duszy funkcję poznawania świata idei. W ten sposób podział człowieka na duszę i ciało został rozszerzony do trychotomii: ciało, niższa część duszy i rozumna część duszy, czyli umysł, który jest najważniejszą częścią człowieka; por. Plato, Phaedo 66b-67 i 79-80a; Meno 88e-89a; Respublica IV 441e; zob. M.A. Krapiec, Ja - człowiek, Lublin 1991, 31-32; T. Špidlik - I. Gargano - V. Grossi, Historia duchowości, t. 3A: Duchowość Ojców greckich i wschodnich, tłum. K. Franczyk - J. Serafin, Kraków 2004, 75; P.F.X. Murphy, The moral virtues in patristic thought, „Seminarium” 9 (1969) 406. Źródła patrystycznej trychotomii człowieka są jednak zasadniczo biblijne (1Tes 5, 23); por. Špidlik - Gargano - Grossi, Historia duchowości, s. 75. W piśmiennictwie wczesnochrześcijańskim nawiązywał do niej Klemens Aleksandryjski, który twierdził, że człowiek składa się z ciała i duszy, w której jest część irracjonalna i duchowa. To ta ostatnia, dokładniej rzecz biorąc, stanowi prawdziwego człowieka; por. Clemens Alexandrinus, Stromata III 10, 68, 5; III 77, 3; V 87, 4; zob. L.F. Ladaria, Człowiek stworzony na obraz Boga, w: Historia dogmatów, red. B. Sesboüé, t. 2: V. Grossi - L.F. Ladaria - Ph. Lécrivain - B. Sesboüé, Człowiek i jego zbawienie, tłum. P. Rak, Kraków 2001, 91; M. Szram, Duchowy sens liczb w alegorycznej egzegezie aleksandryjskiej (II-V w.), Lublin 2001, 191192. Takiego też rozróżnienia w człowieku dokonał Orygenes (Fragmenta in Matthaeum 302); por. Szram, Duchowy sens liczb, s. 192-195; H. Crouzel, Orygenes, tłum. J. Margański, Kraków 2004, 123-129; Ladaria, Człowiek stworzony na obraz Boży, s. 93-94. Podobnie wypowiadał się Augustyn, który pojmował człowieka jako złożonego z ciała i rozumnej duszy, por. Augustinus, De Trinitate VII 4, 7; De quantitate animae XII 22; zob. Ladaria, Człowiek stworzony na obraz Boży, s. 98.

${ }^{14}$ Por. Gregorius Magnus, Moralia III 9, 15; XXVI 28, 52; X 18, 35; III 9, 15; XXIX 17, 31; XXX 5, 20; XIII 5, 5; XXVI 30, 56; VI 33, 52; V 31, 54; VIII 26, 45; V 6, 9; XX 38, 73; X 16, 32; XI 29, 40. W Moraliach często występuje opozycja exterioritas - interioritas rozumiana jako przeciwstawienie tego, co może odwracać od Boga, temu, co pozwala Go spotkać, zob. Dagens, Saint Grégoire, s. 191-195.

${ }^{15}$ Por. Gregorius Magnus, Moralia II 49, 77, CCL 143, 106: „Donum quippe Spiritus quod in subiecta mente ante alia prudentiam, temperantiam, fortitudinem, iustitiam format [...]; In his quattuor virtutibus tota boni operis structura consurgit"; zob. Gwiazda, Życie kontemplacyjne, s. 26; G.R. Evans, The thought of Gregory the Great, Cambridge 1986, 10.

${ }^{16}$ Por. Gregorius Magnus, Moralia II 49, 77, CCL 143, 106: „Intra hos autem quattuor domus angulos filii convivantur, quia intra arcana mentis, quae principaliter his quattuor virtutibus ad summae rectitudinis culmen erigitur, virtutes ceterae quasi quaedam cordis soboles se invicem pascunt"; por. tenże, Homiliae in Hiezechielem Prophetam I 3, 8, CCL 142, 37: „Possumus etiam per quattuor partes principales quattuor virtutes accipere, ex quibus reliquae virtutes oriuntur, videlicet prudentiam, fortitudinem, iustitiam atque temperantiam". Zob. G.C. Carluccio, The seven steps to spiritual perfection according to St. Gregory the Great, Ottawa 1949, 26; Gwiazda, Życie kontemplacyjne, s. 26.24.

${ }^{17}$ Por. M.L. Colish, The stoic tradition from antiquity to the early middle ages, t. 2: Stoicism in 
Zdaniem Papieża, kardynalne cnoty sąjednak niewystarczające, aby stawić opór wszystkim pokusom ${ }^{18}$, dlatego konieczne są następujące dary Ducha Świętego: mądrość (sapientia), rozumienie (intellectus), rozwaga (consilium), męstwo (fortitudo), wiedza (scientia), pobożność (pietas) oraz bojaźń Pana (timor Domini). Umacniają one kardynalne cnoty przez utrwalenie w dobru i zabezpieczają przed możliwymi upadkami ${ }^{19}$. Dary Ducha Świętego, jako nadnaturalne dobra, udoskonalają działanie cnót kardynalnych, które dochodzą do pełnego działania nadprzyrodzonego dopiero przy współdziałaniu siedmiu darów. Przy wzajemnej współpracy cnót i darów Ducha Świętego, człowiek zostaje uzdolniony do przezwyciężenia wszystkich pokus ${ }^{20}$. Dary Ducha Świętego są konieczne do uzyskania i umocnienia stanu duchowej doskonałości oraz do zbawienia, dlatego muszą one trwale istnieć w duszy sprawiedliwego człowieka ${ }^{21}$.

Posiadanie cnót kardynalnych i darów Ducha Świętego nie stanowi jednak pełni duchowej doskonałości człowieka. Dopiero rozwój i działanie cnót teologicznych na podstawie cnót kardynalnych nadaje i zapewnia życiu wewnętrznemu miarę pełni i doskonałości. Człowiek posiadający cnoty kardynalne i wzmocniony przez dary Ducha Świętego, może osiagnąć doskonałość ducha (perfectionis summa) tylko w praktykowaniu cnót teologicznych: nadziei (spes), wiary (fides) i miłości (caritas). Wtedy nie brakuje mu już żadnej cnoty ${ }^{22}$. Chociaż, według Papieża, cnoty teologiczne są bardziej doskonałe w sobie, niż dary Ducha Świętego, to jednak funkcja

Christian Latin thought through the sixth century, Leiden - New York - København - Köln 1990, 264-265.

${ }^{18}$ Por. Gregorius Magnus, Moralia II 49, 76; zob. Carluccio, The seven steps, s. 54.

${ }^{19}$ Por. Gregorius Magnus, Moralia II 49, 77, CCL 143, 106: „Donum quippe Spiritus, quod in subiecta mente ante alia prudentiam, temperantiam, fortitudinem, iustitiam format, eamdem mentem ut contra singula quaeque tentamenta erudiat, in septem mox virtutibus temperat, ut contra stultitiam, sapientiam; contra hebetudinem, intellectum; contra praecipitationem, consilium; contra timorem, fortitudinem; contra ignorantiam, scientiam; contra duritiam, pietatem; contra superbiam det timorem"; tamże II 49, 78; I 27, 38; zob. Carluccio, The seven steps, s. 25-26; W. Furman, Wptyw św. Grzegorza na św. Tomasza z Akwinu w doktrynie o darach Ducha Świętego, Lublin 1961, 3-4 i $19-20$.

${ }^{20}$ Por. Carluccio, The seven steps, s. 27; Furman, Wpływ św. Grzegorza, s. 21; J. Aumann, Zarys historii duchowości, tłum. J. Machniak, Kielce 1993, 91.

${ }^{21}$ Por. Gregorius Magnus, Moralia II 56, 91; Homiliae in Hiezechielem Prophetam I 5, 11; zob. Carluccio, The seven steps, s. 57-58; Furman, Wplyw św. Grzegorza, s. 7-8.

${ }^{22}$ Por. Gregorius Magnus, Moralia XXXV 16, 42, CCL 143B, 1803: „Septem quoque filios, et tres filias recepit [Ecclesia], quia eorum mentibus quos septem virtutibus generat ad perfectionis summam, spem, fidem caritatemque coniungit, ut tanto verius prole sua gaudeat, quanto suis fidelibus nil deesse virtutis pensat”; tamże I 27, 38, CCL 143, 45-46: „Sed habent in nobis septem filii tres procul dubio sorores suas, quia quidquid virile hi virtutum sensus faciunt, spei, fidei caritatique coniungunt. Neque enim ad denarii perfectionem septem filii perveniunt, nisi in fide, spe et caritate fuerit omne quod agent”; tamże XXXV 16, 42; I 33, 46; zob. Gwiazda, Życie kontemplacyjne, s. 28 i 26. 
każdej teologicznej cnoty ożywia się przez natchnienie Ducha Świętego, który działa przez dary ${ }^{23}$. Wtedy dary Ducha Świętego stają się bardziej owocne ${ }^{24}$. Na podstawie analizy powyższych wypowiedzi możemy więc stwierdzić, że trwanie człowieka w duchowej doskonałości, zakłada posiadanie przez niego kardynalnych cnót, darów Ducha Świętego oraz cnót teologicznych. Te trzy grupy duchowych dóbr wiążą się ze sobą w sposób nierozerwalny ${ }^{25}$.

Grzegorz Wielki oprócz przedstawionych cnót wyodrębnia także inne cnoty moralne, które kształtują ludzkiego ducha. W sposób szczególny podkreśla znaczenie pokory (humilitas). Jego zdaniem, pokora utrwala inne cnoty w ich dobrym działaniu pod tym względem, że strzeże, aby przez pokusę pychy nie przerodziły się one w wady. Dlatego cnota ta, według naszego Autora, jest

${ }^{23}$ Por. Gregorius Magnus, Moralia I 33, 46; XXXV 16, 42; zob. Carluccio, The seven steps, s. 29 i 68-69; Furman, Wpływ św. Grzegorza, s. 36-37; Gwiazda, Życie kontemplacyjne, s. 29; Aumann, Zarys historii duchowości, s. 91.

${ }^{24}$ Por. Gregorius Magnus, Moralia I 32, 45-33, 46; XXXV 16, 42; zob. Carluccio, The seven steps, s. 27-28.

${ }^{25}$ Grzegorzowe poglądy w zakresie aretologii stanowią w dużym stopniu kontynuację wcześniejszej tradycji filozoficzno-teologicznej. Idea czterech kardynalnych cnót jest widoczna już w pismach Platona (por. Plato, Respublica IV 427d-435a; zob. J. Seth, Virtue, w: Dictionary of philosophy and psychology, ed. J.M. Baldwin, Gloucester 1960, 764; R. Gillet, Introduction, w: Grégoire le Grand, Morales sur Job (I-II), ed. R. Gillet, SCh 32bis, Paris 1975, 105), stoików (por. Stobaeus, Anthologium II 59, 4; zob. G. Reale, Historia filozofii starożytnej, thum. E.I. Zieliński, t. 3, Lublin 1999, 411-412), Cycerona (por. Cicero, De inventione II 159; zob. G.R. Evans, The thought, s. 110), Plotyna (por. Plotinus, Enneades I 2; zob. B. Świtalski, Plotyn a etyka św. Augustyna, Warszawa 1938, 30), a na gruncie chrześcijańskim w Piśmie Świętym (Mdr 8, 7) (por. G.P. Evans, Cardinal virtues, w: The new dictionary of catholic spirituality, red. M. Downey, Collegeville 1993, 114), Klemensa Aleksandryjskiego (por. Murphy, The moral virtues, s. 407.), Orygenesa (por. Origenes, De principiis IV 4, 2; zob. Murphy, The moral virtues, s. 409), Ambrożego (por. Ambrosius, Expositio Evangelii secundum Lucam V 62; zob. Colish, The stoic tradition, s. 62; Murphy, The moral virtues, s. 415; szerzej na temat aretologii Ambrożego por. J. Pałucki, Święty Ambroży jako duszpasterz w świetle eksportacji pastoralnych, Lublin 1996, 119-162; tenże, Nabywanie cnót $w$ ambrozjańskim programie doskonalenia chrześcijańskiego, s. 77-88) i Augustyna (por. Augustinus, De diversis quaestionibus XXXI 1; De Genesi contra Manichaeos II 10, 14; zob. Colish, The stoic tradition, s. 215; B. Świtalski, Plotyn a etyka św. Augustyna, Warszawa 1938, 56-57; Murphy, The moral virtues, s. 415). Doktryna o siedmiu darach Ducha Świętego została zaczerpnięta z Pisma Świętego (Iz 11, 2-3). Odwoływali się do niej także Ojcowie Kościoła, m.in. Justyn, Orygenes i Augustyn. Umieszczali je jednak w różnych kontekstach (por. G. P. Evans, Gifts of the Holy Spirit, w: The new dictionary of catholic spirituality, s. 436-437). Tak np. Augustyn zestawił siedem darów Ducha Świętego z błogosławieństwami z Kazania na Górze (por. Augustinus, De sermone Domini in Monte I 3, 10-I 4, 11; zob. J. Zbiciak, Augustyn: Myśl ascetyczno-mistyczna, EK I 1112). Również idea cnót teologicznych ma swoje źródło w Piśmie Świętym (1Kor 13, 13). Znajduje odzwierciedlenie u takich Ojców Kościoła, jak m.in. Ambroży (por. Ambrosius, Expositio Evangelii secundum Lucam VIII 30; De Isaac et anima IV 26; zob. Pałucki, Święty Ambroży, s. 156-159) i Augustyn, według którego teologiczne cnoty są konieczne do osiagnięcia Najwyższego Dobra (por. Augustinus, Soliloquia I 6, 12; zob. Świtalski, Plotyn a etyka, s. 58). 
początkiem wszelkiej innej cnoty (origo virtutis) ${ }^{26}$. Inną cnotą, przywoływaną najczęściej przez Grzegorza Wielkiego i mocno związaną z pokorą, jest posłuszeństwo (oboedientia) wobec woli Bożej ${ }^{27}$.

Nowatorstwo Grzegorza Wielkiego w zakresie aretologii polega na tym, że on jako pierwszy zwrócił uwagę na wzajemny stosunek cnót i darów Ducha Świętego ${ }^{28}$. Jest on pierwszym teologiem, który rozwija usystematyzowaną teologię darów Ducha Świętego ${ }^{29}$. Określając zarówno dary Ducha Świętego, jak i cnoty terminem virtus, umieszcza je w tej samej kategorii duchowych dóbr $^{30}$. Autor Moraliów głosi ideę harmonijnego połączenia i współpracy wszystkich cnót: kardynalnych, darów Ducha Świętego i teologicznych. Brak jakiejkolwiek z cnót powoduje, że inne albo wcale nie są cnotami, albo przynajmniej bardzo niedoskonałymi ${ }^{31}$.

${ }^{26}$ Por. Gregorius Magnus, Moralia XXVII 46, 76, CCL 143A, 1390: „Quia enim origo virtutis humilitas est, illa in nobis virtus veraciter pullulat, quae in radice propria, id est in humilitate perdurat; tamże XXV 12, 30; XXXIV 23, 54; zob. Gwiazda, Życie kontemplacyjne, s. 26-27; J. Leclercq, Miłość nauki a pragnienie Boga, tłum. M. Borkowska, Kraków 1997, 45; M. Porcel, La doctrina monastica de S. Gregorio Magno y la „Regula Monachorum”, Madrid 1951, 109-115; R. Gillet, Introduction, s. 93 i 66-67. Znaczenie cnoty pokory podkreślali niemalże wszyscy pisarze wczesnochrześcijańscy, jak Orygenes, Tertulian, Cyprian, Laktancjusz, Bazyli Wielki, Grzegorz z Nazjanzu, Jan Chryzostom, Hilary z Poitiers, Ambroży, Hieronim, Augustyn, Paulin z Noli, Prosper z Akwitanii, Leon Wielki, czy Jan Kasjan; por. S. Witek, Interpretacja pokory w patrystyce zachodniej, RTK 17 (1970) z. 3, 5-24; M. Szram, Pokora - ,,matka cnót” w ujęciu Bazylego Wielkiego i Jana Chryzostoma, RT 51 (2004) z. 4, 43-64; A. Eckmann, Nauka świętego Augustyna o pokorze jako podstawie ascezy chrześcijańskiej, w: Wczesnochrześcijańska asceza, red. F. Drączkowski - J. Pałucki, Lublin 1993, 83-97; O. Schaffner, Christliche Demut. Der hl. Augustinus Lehre von der Humilitas, Würzburg 1959. Cnota ta była uznawana za dobro o szczególnej wartości w duchowości monastycznej; por. E.M. Heufelder G. Braso, Droga ku Bogu według Reguly św. Benedykta, thum. W. Szlęzak - A. Świderkówna, Kraków 1981, 42-46.

${ }^{27}$ Por. Gregorius Magnus, Moralia XXXV 14, 32; zob. Gwiazda, Życie kontemplacyjne, s. $27-$ 28; S. Sojka, Ideat życia kapłańskiego w świetle pism świętego Grzegorza Wielkiego, Lublin 2003, 97-105; Porcel, La doctrina, s. 99-109; A. de Vogüé, The views of St. Gregory the Great on the religious life in his Commentary on the Book of Kings (II), „Cistercian Studies” 17 (1982) 230-231. Grzegorzowe akcentowanie cnoty posłuszeństwa może być zaczerpnięte z duchowości monastycznej; por. Braso, Droga ku Bogu, s. 57-61; Porcel, La doctrina, s. 99-109.200-203.

${ }^{28}$ Por. Furman, Wplyw św. Grzegorza, s. 32-33.

${ }^{29}$ Por. L. Bouyer, Duch Święty Pocieszyciel, tłum. A. Liduchowska, Kraków 1998, 286-288.

${ }^{30}$ Por. Carluccio, The seven steps, s. 53-54.

${ }^{31}$ Por. Gregorius Magnus, Moralia I 32, 45, CCL 143, 49: „Sed illud in hoc filiorum convivio perscrutandum video, quod semetipsos invicem pascunt. Valde enim singula quaelibet virtus destituitur, si non una alii virtus virtuti suffragetur”; tamże XXII 1, 2, CCL 143A, 1092: „Hoc autem primum sciendum est, quia quisquis virtute aliqua pollere creditur, tunc veraciter pollet, cum vitiis ex alia parte non subiacet. Nam si ex alio vitiis subditur, nec hoc est solidum, ubi stare putabatur. Unaquaeque enim virtus tanto minor est, quanto desunt caeterae: [...]";tamże XXII 1, 2; I 27, 38; Homiliae in Hiezechielem Prophetam I 2, 19; zob. R. Gillet, Introduction, s. 106-108; Colish, The stoic tradition, s. 263 i 265; Gwiazda, Życie kontemplacyjne, s. 25; G.R. Evans, The thought, s 10. Podobnie jak przedstawiona powyżej aretologia Biskupa Rzymu tak też idea harmonijnej współ- 
2. Posiadanie cnót podstawą duchowej lączności z Bogiem. Zgodnie z nauczaniem Grzegorza Wielkiego człowiek, który posiada cnoty, trwa $\mathrm{W}$ duchowej łączności z Bogiem. Potwierdzenie takiego przekonania odnajdujemy w Moraliach:

„[...] przez przybycie Ducha w każdym z nas powstaje mądrość, rozumienie, rada, męstwo, wiedza, pobożność oraz bojaźń Pana [...]"32.

Z analizy przytoczonej wypowiedzi możemy wyprowadzić wniosek, że posiadanie wyliczonych darów Ducha Świętego, które Autor Moraliów włączył do kategorii cnót, zakłada przybycie Ducha Świętego (per adventum Spiritus) do człowieka, a dokładniej do jego umysłu. Można więc stwierdzić, że posiadanie cnót jest niemożliwe bez duchowej łączności z Duchem Świętym, z Bogiem. Wyprowadzony wniosek znajduje potwierdzenie także w innym tekście Moraliów, w którym Grzegorz stwierdza, że w darach Ducha Świętego, uzdalniających człowieka do nadnaturalnego życia, Duch Święty trwa zawsze (semper manere). Spośród tych darów wymienia cnotę łagodności (mansuetudo), pokory (humilitas), cierpliwości (patientia), wiary (fides), nadziei (spes) i miłości (caritas) ${ }^{33}$. W innym miejscu Moraliów Papież zwraca uwagę, że nie tylko te wspomniane cnoty uzdalniają człowieka do nadnaturalnego życia, ale wszystkie ${ }^{34}$. Dlatego możemy stwierdzić, że w jego przekonaniu, we wszystkich cnotach trwa Duch Święty. Posiadanie cnót utożsamia się więc ze stanem trwania $\mathrm{w}$ duchowej łączności z Bogiem. Potwierdzeniem takiego poglądu może służyć tekst nawiązujący do Księgi

pracy cnót znajduje odzwierciedlenie we wcześniejszej tradycji. Na temat harmonijnego połączenia wszystkich cnót wypowiadał się Platon (por. Plato, Protagoras 329c-349b; zob. T. Penner, The unity of virtue, „Philosophical Review” 82 (1973) 35-68; G. Vlastos, Platonic studies, Princeton 1981, 221-265; Gillet, Introduction, s. 105), a zwłaszcza stoicy. Według nich wszystkie cnoty są przejawem wiedzy o tym, co dobre i złe i dlatego tworzą jedność. Kto ma jedną cnotę, ten ma wszystkie (por. Diogenes Laertios, Vitae philosophorum VII 125; Stobaeus, Anthologium II 59, 4; II 60, 9; zob. Reale, Historia filozofii, t. 3, s. 411-413; Gillet, Introduction, s. 103-109). Nawiązanie do filozoficznego poglądu o jedności cnót znajduje wyraz między innymi u Klemensa Aleksandryjskiego (por. Clemens Alexandrinus, Stromata II 80, 3; zob. P. Szczur, Oblicza miłości. „, Miłość daje się poznać w sposób wieloraki”. Cnoty pokrewne i towarzyszace ả ó́ $\Uparrow \eta$ wedtug Klemensa Aleksandryjskiego, Lublin 2002, 52-64), Orygenesa (por. M. Szram, Chrystus jako uosobienie cnót wedtug Orygenesa, w: Droga doskonalenia chrześcijańskiego w epoce patrystycznej, red. F. Drączkowski - J. Pałucki - M. Szram, Lublin 1997, 63), Ambrożego (por. Ambrosius, De officiis ministrorum II 8, 43; zob. Colish, The stoic tradition, s. 62-66; Gillet, Introduction, s. 105), Augustyna (por. Augustinus, De moribus Ecclesiae I 15, 25; zob. Colish, The stoic tradition, s. 217-220; J.M. Rist, Augustine. Ancient thought baptized, Cambridge 1997, 161-162).

${ }^{32}$ Gregorius Magnus, Moralia I 27, 38, CCL 143, 45: „[...] per adventum Spiritus, sapientia, intellectus, consilium, fortitudo, scientia, pietas ac timor Domini unicuique nostrum gignitur, [...]", przekłady tekstów Grzegorza pochodzą od autora artykułu.

${ }^{33}$ Por. tamże II 56, 91.

${ }^{34}$ Por. tamże XIX 30, 53. 
Hioba (Hi 29,15), w którym czytamy, że obfitość cnót (turba virtutum) otacza Boga, zasiadającego w umyśle sprawiedliwych ludzi ${ }^{35}$.

Łączność z Bogiem w stanie posiadania cnót Grzegorz Wielki uważa za tak ścisła, że określa ją mianem posiadania Boga. Dowodzi, że dusza człowieka cnotliwego, napełniona darami Ducha Świętego, jest także napełniona miłością (amor) do Boga ${ }^{36}$. U Autora Moraliów miłowanie Boga jest równoznaczne $\mathrm{z}$ pragnieniem $\mathrm{Go}^{37}$. Człowiek zaś, który pragnie, czyli miłuje Boga z całego serca, już Go posiada (habere) w tym życiu ${ }^{38}$. Miłość ta, jako posiadanie Boga, jest rodzajem duchowej wiedzy ${ }^{39}$. Posiadanie Boga nie oznacza jednak, że człowiek włada Bogiem, lecz że znajduje się z Nim w bardzo bliskiej duchowej łączności, uzyskanej za pośrednictwem cnót. Na podstawie powyższych twierdzeń można więc wyprowadzić wniosek, że człowiek posiadający cnoty miłuje Boga, co utożsamia się z trwaniem w ścisłej duchowej łączności z Nim, którą nasz Autor określa jako posiadanie Boga. Można też stwierdzić odwrotnie, że posiadanie Boga zakłada posiadanie cnót z ich umiłowaniem (amor virtutum) ze względu na łączność z Bogiem, która dokonuje się przez ich pośrednictwo ${ }^{40}$. W ten sposób Grzegorz Wielki ukazuje, że cnoty jako dobra duchowe nie są celem samym w sobie, lecz środkiem, za pośrednictwem którego człowiek nawiązuje łączność z Bogiem.

Według Grzegorza Wielkiego, człowiek łącząc się z Bogiem upodabnia się do Niego. Papież naucza, że w ludzkim umyśle, czyli w duchu, odbija się obraz i podobieństwo Boże $e^{41}$. One są naznaczone dynamizmem, wyrażającym się w dążeniu ku doskonałości. Człowiek więc, gdy kieruje się w życiu cnotami,

${ }^{35}$ Por. tamże XX 5, 12, CCL 143A, 1010: „Sive certe quasi rex sedet [Dominus] circumstante exercitu, quia praesidentem illum mentibus electorum circumstat turba virtutum"; zob. tenże, Homiliae in Evangelia II 30, 2, CCL 141, 257: „Qui ergo Deum vere diligit, qui eius mandata custodit, in eius corde Dominus et venit et mansionem facit".

${ }^{36}$ Por. tenże, Homiliae in Hiezechielem Prophetam II 1, 6; Moralia I 27, 38; zob. Carluccio, The seven steps, s. 43-44; Furman, Wpływ św. Grzegorza, s. 5-6.

${ }^{37}$ Por. Gregorius Magnus, Homiliae in Evangelia II 29, 11; II 30, 10. J. Morson dowodzi, że u Grzegorza Wielkiego terminy desiderare, amare i diligere są synonimami, por. J. Morson, Seeking God by desire, „Cistercian Studies” 2 (1967) 175-185.

${ }^{38}$ Por. Gregorius Magnus, Homiliae in Evangelia II 30, 1, CCL 141, 256: „Qui ergo mente integra Deum desiderat, profecto iam habet quem amat. Neque enim quisquam posset Deum diligere, si eum quem diligit non haberet. Sed ecce, si unusquisque vestrum requiratur an diligat Deum, tota fiducia et secura mente respondet, Diligo"; zob. M. Casey, Spiritual desire in the Gospel Homilies of Saint Gregory the Great, „Cistercian Studies” 16 (1981) 302; Leclercq, Miłość nauki, s. 42.

${ }^{39}$ Por. Gregorius Magnus, Homiliae in Evangelia II 27, 4, CCL 141, 232: „Dum enim audita supercaelestia amamus, amata iam novimus, quia amor ipse notitia est. Omnia ergo eis nota fecerat, qui, a terrenis desideriis immutati, amoris summi facibus ardebant"; zob. Casey, Spiritual desire, s. 313.

${ }^{40}$ Por. Gregorius Magnus, Homiliae in Hiezechielem Prophetam I 12.

${ }^{41}$ Pojęcia obraz i podobieństwo Boże Grzegorz Wielki zdaje się traktować jako równoznaczne; por. Gregorius Magnus, Homiliae in Evangelia II 34, 6. 
czyli zmierza do duchowej doskonałości, w swoim umyśle coraz bardziej upodabnia się do $\mathrm{Boga}^{42}$.

${ }^{42}$ Por. tenże, Moralia V 45, 78; V 35, 64; zob. G.R. Evans, The thought, s. 64-65. W Grzegorzowej koncepcji cnót jako dóbr, za pośrednictwem których człowiek łączy się z Bogiem, istnieje wiele nawiązań do wcześniejszych myślicieli zarówno przedchrześcijańskich, jak i chrześcijańskich. Spośród autorów przedchrześcijańskich już Platon i jego kontynuatorzy twierdzili, że dusza doskonali się za pośrednictwem cnoty. Cnota nie jest dobrem samym w sobie, lecz dobrem, które powinno doprowadzić człowieka do łączności z Absolutem przez upodobnienie do Niego, w sposób szczególny przejawiającej się w kontemplacji rzeczywistości ponadzmysłowej. Według Platona, posiadanie cnoty jest zadatkiem pozaziemskiego szczęścia; por. Plato, Gorgias 470; Theaetetus 176; Apologia 38a; Symposium 210e-211b; Phaedrus 249d; Phaedo 69a-d; 113d-115a; Meno 87-89; Protagoras 360d-361; Respublica IX 580c; Leges IV 716-717. Podobne poglądy głosili neoplatonicy, por. Plotinus, Enneades I 4; I 2; I 6; VI 9; zob. Świtalski, Plotyn a etyka, s. 5. Można także znaleźć podobieństwa myśli Grzegorza Wielkiego z poglądami Arystotelesa, który nauczał, że życie polegające na działaniu rozumnym, które jest życiem cnotliwym, w jakiś sposób prowadzi do tego, co wykracza poza wymiar ludzki, do upodobnienia się do życia boskiego; por. Aristoteles, Ethica Nicomachea K7, 1177b-1178a; K 8, 1178b; A 7, 1097b-1098a; A 13, 1102b; B 6, 1106; B 6, 1107a; E 1, 1129b. Istnieje różnica w poglądach na cnotę u Grzegorza Wielkiego i u stoików. Polega ona na tym, że cnota według stoików nie jest środkiem do jakichś wyższych celów, lecz dobrem samym w sobie, por. Diogenes Laertios, Vitae philosophorum VII 89; Stobaeus, Anthologium II 77, 16; zob. M. Forschner, Die stoische Ethik, Darmstadt 1995, 212-226 i 171-182. W przekonaniu o duchowej łączności cnotliwego człowieka z Bogiem Grzegorz Wielki bardziej nawiązuje do autorów wczesnochrześcijańskich. Orygenes, którego nauczanie wywarło wpływ na późniejszych pisarzy, twierdził, że naśladowanie Chrystusa przez praktykę cnót, z którymi się On utożsamia, jest prawdziwym udziałem w Jego istocie. Według Aleksandryjczyka człowiek, który naśladuje Chrystusa i służy $\mathrm{Mu}$, służy wszystkim cnotom i odwrotnie, kto zdobył cnoty, w tym zamieszkał Chrystus. Ponieważ wszystkie cnoty pochodzą od najwyższego Boga, to ostatecznie On sam mieszka w tych, którzy je zachowuja, por. Origenes, Contra Celsum VIII 17; VI 48; VIII 64; Commentarium in Epistulam ad Romanos I 1; VI 11; X 7; zob. M. Szram, Chrystus - Madrość Boża wedtug Orygenesa, Lublin 1997, 103; tenże, Chrystus jako uosobienie cnót, s. 61-63. Ambroży w dużej części nawiązując do stoików, głosił, że cnota jest jedynym i najwyższym dobrem. Ani dobra zewnętrzne, ani dobra ciała, lecz tylko cnota udziela człowiekowi szczęśliwego życia, przez które osiagga się życie wieczne. Jego stwierdzenie, że cnota jest najwyższym dobrem, łagodzi jednak teza, że człowiek cnotliwy trwa w przyjaźni z Bogiem, czyli że cnota jest środkiem łączącym człowieka z Bogiem, por. Ambrosius, De officiis ministrorum II 5, 18; II 1, 1-3; De Iacob et vita beata I 7, 30; zob. J. Pałucki, Rola dziedzictwa kultury klasycznej w nauczaniu św. Ambrożego, w: Ojcowie Kościoła wobec filozofii i kultury klasycznej, red. F. Drączkowski - J. Pałucki - M. Szram, Lublin 1998, 149-163; tenże, Święty Ambroży jako duszpasterz, s. 133-134; R. Palla, Introduzione, w: Ambrosius, De Iacob et vita beata, SAEMO 3, Milano 1982, 219-220; R. Holte, Béatitude et Sagesse. Saint Augustin et le problème de la fin de l'homme dans la philosophie ancienne, Paris 1962, 171-174. Już wcześniej Laktancjusz twierdził, że cnota jest warunkiem wiecznego życia. Zatraca ona samoistną wartość i nabiera charakteru służebnego jako środek do wieczności, por. Lactantius, Divinae institutiones VII 8, 1; VI 4, 11; zob. B. Łapicki, O spadkobiercach ideologii rzymskiej, Łódź 1962, 38. Podobnie wypowiadał się Jan Kasjan, por. Joannes Cassianus, Collationes I 8; XXIII 3; VI 3; zob. C. Stewart, Kasjan mnich, tłum. T. Lubowiecka, ŹM 34, Kraków - Tyniec 2004, 103-106. Św. Augustyn w sposób wyraźny odrzucił stoickie stwierdzenie, że cnota jest celem samym w sobie. Według niego, cnoty są pośrednimi dobrami, środkami do celu, którym jest stan posiadania doskonałej mądrości 
Zdaniem Grzegorza Wielkiego, bliska duchowa łączność z Bogiem w życiu ziemskim znajduje swoją pełnię i najwyższy wyraz w akcie kontemplowania Boga. Papież jest przekonany, że umysł wywyższony przez Bożą łaskę do posiadania dóbr duchowych, przewyższając wszystko, co przemijające, i zgłębiając duchową rzeczywistość, może podnieść się w modlitwie do stanu kontemplacji ${ }^{43}$. Jest ona najbardziej wzniosłym doświadczeniem, do którego może doprowadzić trwanie w łączności z Bogiem i które jest najwyższym wyrazem tej łączności ${ }^{44}$.

\section{Lączność człowieka $\mathrm{z}$ Bogiem zapowiedzią niebiańskiego życia.} Zdaniem Autora Moraliów, człowiek posiadający cnoty, chociaż prowadzi życie na tej ziemi i z tego powodu nie może w pełni uczestniczyć w życiu niebiańskim, może jednak przez złączenie z Bogiem w jakiś sposób kosztować niebiańskiej rzeczywistości. Potwierdzenie takiego przekonania odnajdujemy w tekście Moraliów, nawiązującym do wypowiedzi biblijnych:

„Starą rzeczywistość zapewne starego człowieka ginącego wśród występków opłakiwał ten [psalmista], który mówi: «Zestarzałem się wśród wszystkich nieprzyjaciół moich» (Ps 6, 8). Przeciwnie inny [autor Księgi Koheleta] zachęcając do radowania się cnotami mówi: «Raduj się, młodzieńcze, w młodości swojej» (Koh 2, 9). Jak gdyby mówił: Każdy dzielny niech się raduje w swoim odnowieniu, to znaczy niech nie pokłada swojej radości w przyjemności starego sposobu życia, lecz w cnocie nowego sposobu życia" ${ }^{45}$.

\footnotetext{
i prawdy w samym Bogu, utożsamiający się z poznaniem Boga i posiadaniem Go. Przedstawione dotąd poglądy Augustyna są bardzo podobne do poglądów Grzegorza Wielkiego. Biskup Hippony jednak wraz z rozwojem swojej myśli zmienił pogląd w tej kwestii. Według niego, nie ma mędrców wśród ludzi w życiu ziemskim, a więc nie ma ludzi, którzy poznaliby i posiadali Boga. Człowiek pozna Boga tylko w życiu po cielesnej śmierci, por. Augustinus, De moribus Ecclesiae XV 25; XIX 35 - XXV 47; XXII 41; XIV 24; De musica VI 16, 52; Soliloquia I 6, 12; Enarrationes in Psalmos 83, 11; zob. W.S. Babcock, „Cupiditas” and „Caritas”: The early Augustine on love and human fulfilment, w: The ethics of St. Augustine, red. W.S. Babcock, Atlanta 1991, 49 i 52-53; Colish, The stoic tradition, s. 213 i 216-219; Świtalski, Plotyn a etyka, s. 40.

${ }^{43}$ Por. Gregorius Magnus, Moralia XXXI 49, 99; VIII 30, 49; V 30, 53; X 18, 34; zob. Porcel, La doctrina, s. 141-147.

${ }^{44}$ Por. Gwiazda, Życie kontemplacyjne, s. 107-108; Gillet, Introduction, s. 36-48. Chociaż Grzegorz Wielki podkreśla, że trwanie w łączności z Bogiem jest doniosłe, to jednak jest zdania, iż etap ten, pomimo, że jest w kontemplacji niezbędny, jest niewystarczający. Według Biskupa Rzymu są ludzie, którzy miłują Boga i pełnią dobre dzieła, a nie znają radości kontemplacji, ponieważ kontemplacja wymaga szczególnego przygotowania ducha; por. Gregorius Magnus, Homiliae in Hiezechielem Prophetam II 5, 1; Moralia VIII 24, 41; V 28, 50; V 33, 58-60; V 36, 66; XVIII 50, 82; zob. Gwiazda, Życie kontemplacyjne, s. 35-65; Gillet, Introduction, s. 68-72; Rosik, Finalizm, s. 188, 210 i 221-222; P. Catry, Les voies de l'Esprit chez Grégoire, w: Grégoire le Grand. Colloques internationaux du Centre National de la Recherche Scientifique, ed. J. Fontaine - R. Gillet - S. Pellistrandi, Paris 1986, 207-214; Carluccio, The seven steps, s. 47-49.

${ }^{45}$ Gregorius Magnus, Moralia XXIV 4, 8, CCL 143B, 1194: „Senectutem quippe veteris homi-
} 
W powyższej wypowiedzi możemy zauważyć, że Papież przeciwstawia starą rzeczywistość człowieka (senectus, vita vetus), powiązaną z występkami (vitia), nowej rzeczywistości człowieka (renovatio, conversatio nova), utożsamianej z cnotami (virtutes). Twierdzi, że autor Księgi Koheleta zachęca do radowania się $w$ cnotach (gaudere in virtutibus), później dodaje, że ten sam autor biblijny zdaje się zachęcać, aby każdy dzielny człowiek radował się $\mathrm{w}$ swoim odnowieniu (fortis quisque gaudeat in renovatione sua). W celu wyjaśnienia, co Grzegorz Wielki rozumie przez odnowienie, należy zaznaczyć, że powyższy tekst został umieszczony w kontekście wypowiedzi o Chrystusowym przyjściu na świat ziemski, w celu odnowienia człowieka do nieskazitelności poprzedniego, rajskiego życia (prioris vitae integritas). Odnowienie więc, według Grzegorza Wielkiego, oznacza zbawienie człowieka, dokonane przez Chrystusa. Odnowienie to, jak wykazaliśmy wyżej, Papież utożsamia z posiadaniem cnót, dlatego należy wnioskować, że zbawcza rzeczywistość nowego życia, udostępniona człowiekowi przez Chrystusa, uobecnia się już w cnotach jeszcze za ziemskiego życia człowieka. Posiadanie cnót jest więc zadatkiem uczestnictwa w niebiańskiej rzeczywistości ${ }^{46}$. Przekonanie to znajduje potwierdzenie w wypowiedziach dotyczących teologicznych cnót nadziei i wiary. W nich Autor Moraliów stwierdza, że nadzieja podnosi ducha ludzkiego do wieczności ${ }^{47}$, a w wierze zaczyna się w tym życiu oglądanie Boga, które w przyszłości dokona się w pełnym widzeniu ${ }^{48}$.

Stan uczestniczenia sprawiedliwego człowieka w niebiańskiej rzeczywistości w życiu ziemskim, Grzegorz uważa za niebiańskie życie. Papież podkreśla, że człowiek w stanie posiadania cnót, przez które łączy się z Bogiem, prowadzi życie nadprzyrodzone ${ }^{49}$. Jest ono doskonałością dodaną do naturalnego życia, którą można uzyskać tylko przy pomocy darów Ducha Świętego ${ }^{50}$. Jest ono przeciwieństwem śmierci, rozumianej jako stan przebywania człowieka w grzechu ${ }^{51}$. Dlatego Autor Moraliów uważa stan posiadania duchowych dóbr za synonim życia ${ }^{52}$. Właśnie życie, zjednoczone z Bogiem i przeniknięte darami Ducha Świętego, ze względu na ścisłą łączność

\footnotetext{
nis inter vitia tabescentem deflebat ille qui ait: «Inveteravi inter omnes inimicos meos» (Ps 6, 8). E contra alius gaudere in virtutibus admonens, dicit: «Laetare, iuvenis, in adolescentia tua» (Koh 2, 9). Ac si diceret: Fortis quisque gaudeat in renovatione sua; id est, laetitiam suam non in vitae veteris voluptate, sed in conversationis novae virtute constituat".

${ }^{46}$ Por. tamże XIX 30, 53; zob. Rosik, Finalizm, s. 108.

${ }^{47}$ Por. Gregorius Magnus, Moralia VI 22, 39.

${ }^{48}$ Por. tamże XVIII 54, 93.

${ }^{49}$ Por. tamże XVIII 54, 92; XIX 30, 53; I 27, 38; tenże, Dialogi IV 47.

${ }^{50}$ Por. Carluccio, The seven steps, s. 41-42; Rosik, Finalizm, s. 107, 136-137 i 172-177; Furman, Wpływ św. Grzegorza, s. 19-20.

${ }^{51}$ Por. Gregorius Magnus, Moralia XIX 30, 53; XXIX 32, 76.

${ }^{52}$ Por. tamże I 35, 50, CCL 143, 51: „Atque in inguine feriunt [maligni spiritus], quia virtutem
} 
z rzeczywistością niebiańską, Papież określa mianem życia niebiańskiego

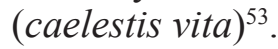

Autor Moraliów naucza, że stan uczestniczenia człowieka w niebiańskim życiu za pośrednictwem cnót, utożsamia się ze stanem szczęścia ${ }^{54}$. Papież pisze, że z tego powodu, iż grzech zabija duszę i odcina ją od wewnętrznego, czyli nadprzyrodzonego życia ${ }^{55}$, ta dusza, która została opanowana przez główne grzechy (principalia vitia), jest nieszczęśliwa (infelix) ${ }^{56}$. Na tej podstawie można stwierdzić, że dusza uwolniona od grzechów, jako przeciwieństwa cnót, jest szczęśliwa. W tym kontekście na uwagę zasługuje następująca wypowiedź Papieża:

„Ponieważ groby ukrywają zmarłych, cóż innego oznaczają groby, niż niegodziwych, w których odcięte od szczęśliwego życia dusze pozostają jakby ukryte w grobach?"57.

W powyższym zdaniu Grzegorz Wielki zwraca uwagę, że ludzie niegodziwi (reprobi), czyli ludzie przebywający w stanie grzechu, a więc nie troszczący się o cnoty, są odcięci od szczęśliwego życia (a vita beatitudinis). $\mathrm{Z}$ takiego przekonania można wyprowadzić wniosek, że ludzie sprawiedliwi, posiadający cnoty żyją szczęśliwie. Należy zwrócić uwagę, że użycie przez Autora zwrotu vita beatitudinis może świadczyć, iż szczęśliwe życie w czasie obecnym jest początkiem i zadatkiem życia szczęśliwego w wieczności, które nasz Autor bardzo często określa terminami, spokrewnionymi pod względem rdzenia z rzeczownikiem beatitudo ${ }^{58}$.

cordis delectatione carnis occidunt. In inguine quippe ferire, est vitam mentis delectatione carnis perforare".

${ }^{53}$ Por. tamże XVIII 53, 87, CCL 143A, 950: „Hinc est enim quod sponsi voce de sancta Ecclesia dicitur: «Quae est ista quae ascendit dealbata?» (Pnp 8, 5). Quia enim Sancta Ecclesia caelestem vitam naturaliter non habet, sed superveniente Spiritu, pulchritudine donorum componitur, non alba sed dealbata memoratur".

${ }^{54} \mathrm{Na}$ temat istoty duchowego szczęścia w życiu ziemskim por. O. Kashchuk, Utrapienie a prawdziwe ziemskie szczéście w nauczaniu Grzegorza Wielkiego, VoxP 27 (2007) t. 50-51, 380-384.

${ }_{55}^{5}$ Por. Gregorius Magnus, Moralia XIV 16, 19.

${ }^{56}$ Por. tamże, XXXI 45, 90. Klasyfikacja wad u Grzegorza Wielkiego nawiązuje do Augustyna i Kasjana. Podobnie jak Augustyn (De Genesi ad litteram XI 15, 19), w pysze Grzegorz Wielki dostrzega źródło wszystkich wad (Moralia XXXI 45, 87-88). Sam podział wad zgadza się z podziałem Kasjana (De institutis caenobiorum V 1); zob. Rosik, Finalizm, s. 48; Gillet, Introduction, s. 89-93.

${ }^{57}$ Gregorius Magnus, Moralia XV 59, 70, CCL 143A, 795: „Quia sepulcra mortuos tegunt, quid aliud per sepulcra quam reprobi designantur, in quibus exstinctae a vita beatitudinis animae velut in sepulcris latent?".

${ }^{58}$ Por. tamże IX 49, 75; VI 23, 40; XVII 3, 4; IV 36, 72; VII 3, 3; IV 28, 54; XXXV 14, 25; VII 5, 5; XV 47, 53; XVIII 48, 77; VI 30, 48; XXXV 19, 46; VI 23, 40; XVIII 48, 79; XXXV 14, 28; XXXV 8, 16; VIII 52, 89; XXIX 2, 4. Grzegorzowe znaczenie terminu beatitudo zakorzenione jest w tradycji starożytnej i nie odbiega zasadniczo od znaczeń występujących w łacińskim piśmiennictwie; por. Słownik łacińsko-polski, red. M. Plezia, t. 1, Warszawa 1998, 351-352; A. Blaise, Dictionnaire Latin-Français des Auteurs Chrétiens, Paris 1954, 111. 
W celu potwierdzenia powyższego przekonania należy odwołać się do Grzegorzowej interpretacji następujących słów Apokalipsy:

„Szczęśliwy i święty ten, kto ma udział w pierwszym zmartwychwstaniu (Ap 20, 6)".

Autor Moraliów wyjaśnia, że w przyszłości ten człowiek szczęśliwie (feliciter)zmartwychwstaniew ciele, któryżyjąc na tej ziemi, zmartwychwstanie ze śmierci swojego umysłu. Powstanie ze śmierci umysłu oznacza nabycie cnót uzdalniających do nadprzyrodzonego życia. Odnosząc wyprowadzone wnioski do cytowanego powyżej fragmentu Apokalipsy, możemy stwierdzić, że człowiek prowadzący nadprzyrodzone życie, jest szczęśliwy (beatus), ponieważ ma zapewnione zmartwychwstanie do szczę́liwego życia w wieczności. Szczęście wieczne tego człowieka zaczyna sięjuż teraz w stanie posiadania cnót ${ }^{59}$.

Podsumowując należy stwierdzić, że zgodnie z nauczaniem Grzegorza Wielkiego posiadanie cnót jest ściśle związane $\mathrm{z}$ uczestniczeniem człowieka w niebiańskiej rzeczywistości. Cnoty są duchowymi dobrami, za pośrednictwem których człowiek duchowo łączy się z Bogiem. Trwanie w duchowej łączności z Nim powoduje, że człowiek już w życiu ziemskim uczestniczy w rzeczywistości życia niebiańskiego. Papież uważa ten stan za niebiańskie i szczęśliwe życie.

\section{THE POSSESSION OF VIRTUES AS FORETASTE OF THE CELESTIAL LIFE IN THE TEACHING OF ST. GREGORY THE GREAT}

\section{(Summary)}

The article discusses a question of the interrelation between the possession of virtues and participation in the reality of the celestial life according to the teaching of St. Gregory the Great. St. Gregory teaches that virtues are the spiritual goods, by means of which a human being acquires the spiritual unity with God. Lasting in the spiritual unity with God causes that a human being, already in the earthly life, participates in the reality of the celestial life. Gregory the Great esteems this state as the celestial and happy life.

${ }^{59}$ Por. Gregorius Magnus, Moralia XIV 16, 19, CCL 143A, 708: „Unde scriptum est: «Beatus et sanctus qui habet partem in resurrectione prima» (Ap 20,6); quia ille post in carne feliciter resurget, qui in hac vita positus, a mentis suae morte resurrexerit". 
